\title{
The Correlation between Vehicle Age and Vehicle Operating Cost of Public Transportation in Banjar Regency
}

\author{
Farida Purnamawati ${ }^{1}$ and Iphan F. Radam $^{2}$ \\ Graduate Student ${ }^{1}$ and Associate Professor ${ }^{2}$ \\ ${ }^{1-2}$ Magister Study Program of Civil Engineering \\ Lambung Mangkurat University \\ Banjarmasin \\ Indonesia
}

\begin{abstract}
Public transportation operating in Banjar Regency is a type of mikrolet (microbus) serving urban and rural areas in Banjar Regency. The number of public transportation operating from year to year is continuously decreasing. The decreasing number of public transportation is caused by the operators' income, which is not as expected. One of the factors that influence operators' income is Vehicle Operating Cost. This research aims to analyze the correlation between the age of public transportation and the vehicle operating cost as well as to get the dominant variable influencing the vehicle life age. The method conducted in analyzing the correlation between the vehicle life age and the variable of vehicle operating cost is by carrying out regression and looking for the best equation. The data needed is in the form of primary and secondary data. Secondary data was obtained from the Banjar Regency Transportation Agency and primary data was obtained through interviews with drivers or public transportation owners. The results of this research indicate that there is a very strong correlation between the vehicle life age and the vehicle operating cost. The correlation between the vehicle life age and the VOC of public transportation in Banjar regency has a very strong at the age of $\leq 25$ years with the value of 0.901 and at the age of more than 25 years with the value 0.995 with the two age groups forming an exponential equation. VOC variable due to increasing vehicle life age will be a very dominant influence on $V O C$ when the vehicle is > 25 years old, namely variables of fixed cost, depreciation cost, maintenance cost, and oil cost.
\end{abstract}

Key Words: Vehicle Operating Cost, Vehicle life age, Public Transportation.

\section{INTRODUCTION}

Public transportation services have an important role in improving public transportation in various regions. Public transportation operating in Banjar Regency has decreased in number. The condition of the decline in the number of public transportation in operation shows that public transportation is not able to survive. Thus, a decrease in the number of public transportation always occurs in Banjar Regency every year. The decline in public transportation interest greatly influences the sustainability of public transportation which has an impact on decreasing income of transportation operators. The factors influencing the demand for transportation services include the prices of transportation services that include many kinds of costs, and not just the cost of transportation services [1]. One of the factors that influence operators' income is Vehicle Operating Cost. In PM 98 of 2013 [2] concerning Minimum Service Standards for Public transportation of Vehicles in Routes which came into force on 10 February 2015, it is stated that the age limit for Inter-city Inter Province $(A K A P)$ and Intercity within province $(A K D P)$ vehicles is regulated no later than 25 years or stipulated by the permit issuer in accordance with regional conditions so that the vehicle operates efficiently and economically. The effect of vehicle life age on the feasibility of operating city bus public transportation in Surakarta City to find out the life of passenger public vehicles that are still feasible to operate in terms of vehicle operating costs, especially city buses in Surakarta City [3].

\section{LITERATURE REVIEW}




\subsection{Vehicle Operating Cost}

According to the Decree of the Minister of Transportation No. KM. 89 of 2002 [4], concerning the mechanism for determining tariffs and formulas for calculating the cost of passenger transportation by public buses, grouping the basic costs of operating a vehicle according to its relation to the production of services produced is divided into:

\subsubsection{Direct Cost}

Direct costs are expenses that are directly related to the service products produced, which consist of fixed cost and variable cost. The calculation is that some of the costs can be directly calculated per km of vehicles, but some of the costs are calculated per $\mathrm{km}$ of vehicles after the annual cost has been calculated. Examples of direct costs are crew salaries, fuel, and terminal cost.

\subsubsection{Indirect Cost}

Indirect costs are expenses that are indirectly related to the service products produced, which consist of fixed cost and variable cost. The calculation cannot be directly per $\mathrm{km}$ of the vehicle because it contains components that are not directly related to the vehicle operation. Examples of indirect costs include: maintenance costs general/office costs, interest/money value costs, taxes.

\subsubsection{Basic Cost}

The basic cost per kilometer vehicle is calculated by summing direct costs and indirect costs. Vehicle operating costs (VOC) are the total expenses incurred by road users using certain modes from the origin zone to the destination zone. The total cost referred to is the actual cost incurred.

Vehicle operating costs consist of two components, namely fixed costs and variable costs [5].

a. Fixed costs are expenses which remain in expenditure without depending on the production volume that occurs. Fixed costs for passenger public transportation consist of 4 cost components, including:

1. Vehicle Depreciation

Collecting money is a standard method used for vehicle replacement, done by setting aside a portion of the income earned during the lifetime of the vehicle. This money is referred to as depreciation costs. Depreciation costs can be treated as a component of fixed costs, if the lifetime of the vehicle is calculated based on time. To calculate depreciation costs, the first thing to conduct is to determine the price of the vehicle.

2. Licensing and Administration

3. Operator Salary

4. Insurance

b. Running Costs are expenses incurred when the vehicle is operating. Variable costs vary greatly depending on the results produced. The cost components included in these non-fixed costs are: fuel cost, lubricant/oil usage cost, tire usage cost, repairs and maintenance costs.

Vehicle operating costs consist of the following components [6]: consumption of fuel oil, consumption of oil and lubricants, tire usage, vehicle repair and maintenance, depreciation, insurance, licensing fees for public transportation, wages from operators or drivers and driving license fees, garage rentals, bank interest rates for capital investment, supervision and unexpected costs.

\subsection{Regression Analysis}

Regression analysis is a study that involves the problem of finding correlations between variables. Correlations obtained are generally expressed in the form of equations and are called regression equations [7]. Regression analysis is useful for getting functional correlations between two or more variables. In addition, regression analysis is useful to get the influence between predictor variables on the variable criteria or predict the influence of predictor variables on variable criteria [8]. The results of the calculation of the regression analysis/test will be included in the research conclusions and will determine whether the research being carried out is successful or not. Simple linear regression is used only for one independent variable and one dependent variable, while multiple linear regression is used for one dependent variable and two or more independent variables [9]. Simple linear regression equation is an equation model that describes the correlation of one independent/predictor variable (X) with one non-free variable/response (Y), which is usually depicted in a straight line.

Correlation analysis is a study that discusses the degree of correlations between variables. Correlation coefficients are a measure of the degree of correlations especially for quantitative data named [7]. The strength of the correlation between predictor variable $\mathrm{x}$ and response $\mathrm{y}$ is measured by correlation analysis whose results are expressed by a number known as the correlation coefficient. Generally, regression analysis is often conducted together with correlation analysis. The correlation coefficient model as shown in Table $1[10]$.

Table1. Interpretation of Correlation Coefficient 
International Journal of Advances in Scientific Research and Engineering (ijasre), Vol 5 (9), September-2019

\begin{tabular}{cl}
\hline $\begin{array}{c}\text { Absolute value of the } \\
\text { correlation coefficients }(|\mathrm{r}|)\end{array}$ & \multicolumn{1}{c}{ Interpretation } \\
\hline $0,00-0,199$ & Slight correlation; almost negligible correlation \\
$0,20-0,399$ & Low correlation; definite but small correlation \\
$0,40-0,699$ & Moderate correlation; substantial correlation \\
$0,70-0,899$ & High correlation; marked correlation \\
$0,90-1,000$ & Very high correlation; very dependable correlation \\
\hline
\end{tabular}

\section{RESEARCH METHODOLOGY}

\subsection{Data Required}

\subsubsection{Secondary Data}

Data is sourced from the Department of Transportation of the Banjar Regency.

\subsubsection{Primary data}

Data is obtained directly in the field by means of surveys. The method used is a survey by interviewing public transportation owners and public transportation drivers.

\subsection{Stages of Data Analysis:}

1. Transportation data in the form of vehicle life age and VOC.

2. Analysis of the correlation between VOC and vehicle life age.

3. If there is a form of equation with $\mathrm{R}^{2}>0.7$, the equation can be used to show the correlation between VOC and the vehicle life age.

\section{ANALYSIS AND DISCUSSION}

The data taken was 55 respondents' data, then when the regression was conducted, it showed less good results so that the reduction of some data samples was carried out. The reduction was carried out because of incompatibility and incomplete data, then an analysis of 29 data was carried out.

\subsection{VOC Analysis}

VOC analysis of urban/rural public transportation is by calculating the fixed costs and non-fixed costs incurred by the operator.

Components that are taken into account in calculating are: licensing costs, depreciation costs, maintenance costs, fuel costs, and operating costs.

Calculation Example:

For Route Code N, Route: Martapura Kelampaian Ilir, Distance of 18 km x $2=36$ km (round trip)

1. Production Average Distance:
a. Vehicle operation per week
b. Amount of trip per day
c. Production distance per day
d. Production distance per year

$$
\begin{aligned}
& =7 \text { days } \\
& =\text { once (round trip) } \\
& =36 \mathrm{~km} \\
& =7 \times 1 \times 36 \times 48 \\
& =12,096 \mathrm{~km}
\end{aligned}
$$

Assumption: number of weeks in one year $=48$ weeks

2. Fixed cost

$\begin{array}{ll}\text { a. } & \text { Vehicle Tax Fee per year } \\ \text { b. } & \text { Route License Fee per year } \\ \text { c. } & \text { KIR (Motorized Vehicle Testing) Fee per year } \\ \text { d. } & \text { Insurance Fee per year } \\ \text { e. } & \text { Total Fixed Cost per year } \\ \text { f. } & \text { Production distance per year }=12,099 \mathrm{~km} \\ \text { g. } & \text { Fixed fee per year }(\mathrm{IDR} / \mathrm{km})\end{array}$

$=$ IDR 262,000

$=$ IDR 150,000

$=$ IDR 170,000

$=$ IDR 240,000

$=$ IDR 822,000

$=$ IDR 67.9

3. Depreciation Cost 
International Journal of Advances in Scientific Research and Engineering (ijasre), Vol 5 (9), September-2019

Depreciation per year $=$ price of a new vehicle - remaining value of the vehicle

\section{Economic Age}

Vehicle residual value $=$ Vehicle selling price $-20 \%$ of vehicle selling price

Economic life/useful life of mikrolet (microbus) $=5$ years

Calculation Example:

The selling price of mikrolet now is IDR 16,500,000

Residual Value $=0.2 \times 16,500,000=3,300,000$,-

Depreciation per year $=\underline{130,000,000-(16,500,000-3,300,000)}$

$$
=\text { IDR 23,360,000 }
$$

4. Maintenance Cost

$\begin{array}{lllr}\text { a. } & \text { Engine oil cost per year } & \text { IDR } & 1,280,000 \\ \text { b. } & \text { Axle oil cost per year } & \text { IDR } & 600,000 \\ \text { c. } & \text { Fees for shipping per year } & \text { IDR } & 36,670 \\ \text { d. } & \text { Brake oil cost per year } & \text { IDR } & 40,000 \\ \text { e. } & \text { Platinum fee per year } & \text { IDR } & 35,000 \\ \text { f. } & \text { Condenser cost per year } & \text { IDR } & 35,000 \\ \text { g. } & \text { The cost of spark plugs per year } & \text { IDR } & 65,000 \\ \text { h. } & \text { Oil filter cost per year } & \text { IDR } & 25,000 \\ \text { i. } & \text { The cost of brake canvas per year } & \text { IDR } & 17,500 \\ \text { j. } & \text { Clutch plate fee per year } & \text { IDR } & 26,670 \\ \text { k. } & \text { Annual fee per year } & \text { IDR } & 216,670 \\ \text { l. } & \text { Front and rear wheel bearings per year } & \text { IDR } & 35,000 \\ \text { m. } & \text { Engine service cost per year } & \text { IDR } & 1,700,000 \\ \text { n. } & \text { Body service cost per year } & \text { IDR } & 1,100,000 \\ \text { o. } & \text { Vehicle washing per year } & \text { IDR } & 720,000 \\ \text { p. } & \text { Fee for tire replacement per year } & \text { IDR } & 760,000 \\ \text { q. } & \text { Total Cost per year } & \text { IDR } & 6,693,000 \\ \text { r. } & \text { Distance per year }(k m)=12,096 & & \\ \text { s. } & \text { Cost (IDR/Km) = 17/18 } & \text { IDR } & 553,282\end{array}$

5. Fuel cost
a. Vehicle operation per week
b. Vehicle operation per year $=7 \times 48$ weeks
c. Fuel consumption per day
d. Fuel consumption per year
e. Annual fuel cost
f. (Assuming that BBM = IDR 6,550/liter)

6. Total of VOC
a. Fixed cost per year
b. Depreciation cost
c. Maintenance cost per year
d. Fuel cost
e. Operating cost
f. Total of VOC per year Total of VOC (IDR/km)

$=$ IDR $\quad 822,000$

$$
\begin{aligned}
& =\text { IDR } 23,360,000 \\
& =\text { IDR } \quad 6,693,000 \\
& =\text { IDR } 11,004,000 \\
& =\text { IDR } 16,800,000 \\
& =\text { IDR } 57,958,500 \\
& =\text { IDR } 4,792
\end{aligned}
$$


International Journal of Advances in Scientific Research and Engineering (ijasre), Vol 5 (9), September-2019

\begin{tabular}{|c|c|c|c|c|c|c|c|c|}
\hline $\begin{array}{c}\text { No. } \\
\text { Sample }\end{array}$ & Age & $\begin{array}{c}\text { Maintenance } \\
\text { Cost }\end{array}$ & $\begin{array}{c}\text { Fixed } \\
\text { Cost }\end{array}$ & $\begin{array}{l}\text { Tired } \\
\text { Cost }\end{array}$ & $\begin{array}{l}\text { Fuel } \\
\text { Cost }\end{array}$ & $\begin{array}{c}\text { Oil } \\
\text { Cost }\end{array}$ & $\begin{array}{c}\text { Depreciation } \\
\text { Cost }\end{array}$ & $\begin{array}{l}\text { Total } \\
\text { VOC }\end{array}$ \\
\hline 1 & 30 & 553 & 68 & 63 & 1000 & 162 & 1.931 & 1.110 \\
\hline 2 & 29 & 441 & 56 & 55 & 656 & 137 & 1.611 & 1.170 \\
\hline 3 & 28 & 447 & 49 & 50 & 708 & 130 & 1.297 & 1.210 \\
\hline 4 & 27 & 358 & 35 & 73 & 786 & 99 & 960 & 1.211 \\
\hline 5 & 26 & 209 & 25 & 27 & 678 & 70 & 685 & 1.218 \\
\hline 6 & 25 & 216 & 23 & 47 & 737 & 53 & 592 & 1.187 \\
\hline 7 & 25 & 216 & 19 & 34 & 696 & 70 & 493 & 1.209 \\
\hline 8 & 24 & 187 & 20 & 20 & 655 & 63 & 490 & 1.210 \\
\hline 9 & 24 & 146 & 20 & 15 & 737 & 55 & 490 & 1.198 \\
\hline 10 & 23 & 155 & 23 & 39 & 737 & 44 & 486 & 1.232 \\
\hline 11 & 22 & 143 & 21 & 17 & 737 & 54 & 483 & 1.261 \\
\hline 12 & 21 & 166 & 22 & 35 & 737 & 33 & 479 & 1.236 \\
\hline 13 & 20 & 159 & 21 & 34 & 655 & 56 & 483 & 1.248 \\
\hline 14 & 20 & 213 & 36 & 39 & 614 & 61 & 476 & 1.237 \\
\hline 15 & 19 & 148 & 23 & 22 & 614 & 58 & 472 & 1.257 \\
\hline 16 & 19 & 125 & 22 & 17 & 614 & 32 & 476 & 1.339 \\
\hline 17 & 19 & 122 & 36 & 20 & 614 & 32 & 476 & 1.319 \\
\hline 18 & 18 & 130 & 24 & 17 & 614 & 42 & 469 & 1.403 \\
\hline 19 & 16 & 116 & 27 & 22 & 655 & 31 & 462 & 1.384 \\
\hline 20 & 16 & 132 & 24 & 20 & 614 & 48 & 462 & 1.401 \\
\hline 21 & 15 & 102 & 24 & 6 & 614 & 43 & 458 & 1.392 \\
\hline 22 & 14 & 117 & 25 & 22 & 614 & 35 & 455 & 1.351 \\
\hline 23 & 14 & 115 & 25 & 22 & 614 & 49 & 455 & 1.424 \\
\hline 24 & 13 & 96 & 25 & 20 & 614 & 28 & 451 & 1.567 \\
\hline 25 & 13 & 127 & 25 & 22 & 614 & 52 & 451 & 1.596 \\
\hline 26 & 12 & 123 & 26 & 20 & 614 & 50 & 448 & 2.139 \\
\hline 27 & 12 & 122 & 26 & 30 & 614 & 29 & 448 & 2.501 \\
\hline 28 & 12 & 81 & 27 & 15 & 614 & 40 & 448 & 2.763 \\
\hline 29 & 9 & 83 & 23 & 16 & 655 & 45 & 350 & 3.462 \\
\hline
\end{tabular}

\subsection{Effect of Vehicle Life Age on the VOC}

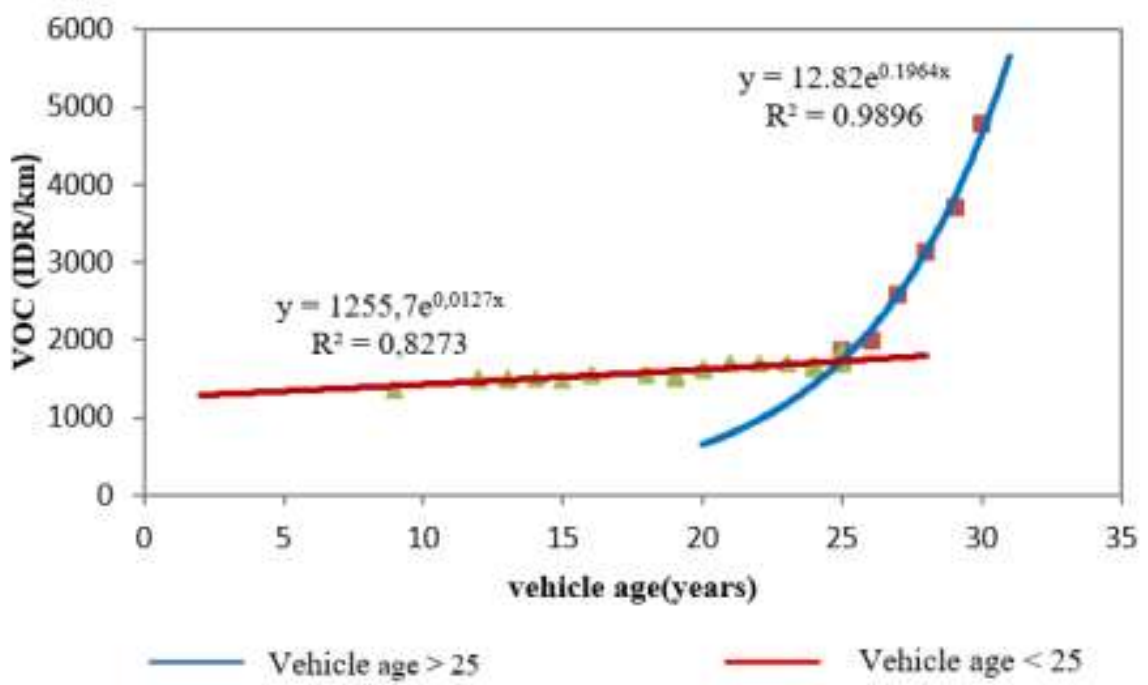

Figure1. Effect of Vehicle Life Age on the VOC

Figure 1 shows that the correlation between the vehicle life age and the total BOK, which is at the age of 0 to 25 years, has a very strong correlation, which is indicated by the value of $\mathrm{R} 2=0.8273$ or $\mathrm{r}=0.901$ and there is a VOC increase of $1.3 \%$ per year. It is obtained that the equation $y=1255.7 \mathrm{e}^{0,0127 x}$. At the age of the vehicle above 25 years, it is obtained that the value of R2 $=0.9896$ or $\mathrm{r}=0.995$ can be defined that there is a very strong correlation and there is an increase in the VOC very rapidly, amounting to $21.7 \%$ per year. It is obtained that correlation equation $\mathrm{y}=12,82 \mathrm{e}^{0,1964 \mathrm{x}}$. Where $\mathrm{y}=$ Vehicle Operating Cost $(\mathrm{IDR} / \mathrm{km})$ and $\mathrm{x}=$ vehicle life age (year). 


\subsection{Effect of Vehicle Life Age on the Fixed Cost Variable}

Fixed cost variable is the cost incurred for payment of vehicle tax, fees for payment of route extension licenses, costs incurred for vehicle KIR payments, and costs for insurance services for one year in units of IDR/kilometers. Figure 2 shows the correlation between fixed costs and vehicle life age, which is at the age of vehicles 0-25. The effect of vehicle life age on fixed costs has a weak correlation, which is indicated by the value of $R^{2}=0.1334$ or $r=0.365$ and the percentage of cost reduction is around $1.2 \%$ per year. In vehicles over the age of 25 years, there is a very strong correlation between fixed expenditure costs and the vehicle life age, which is indicated by the value of $\mathrm{R}^{2}=0.9733$ or $\mathrm{r}=0.987$ and the percentage increase in costs is by $28.2 \%$ per year.

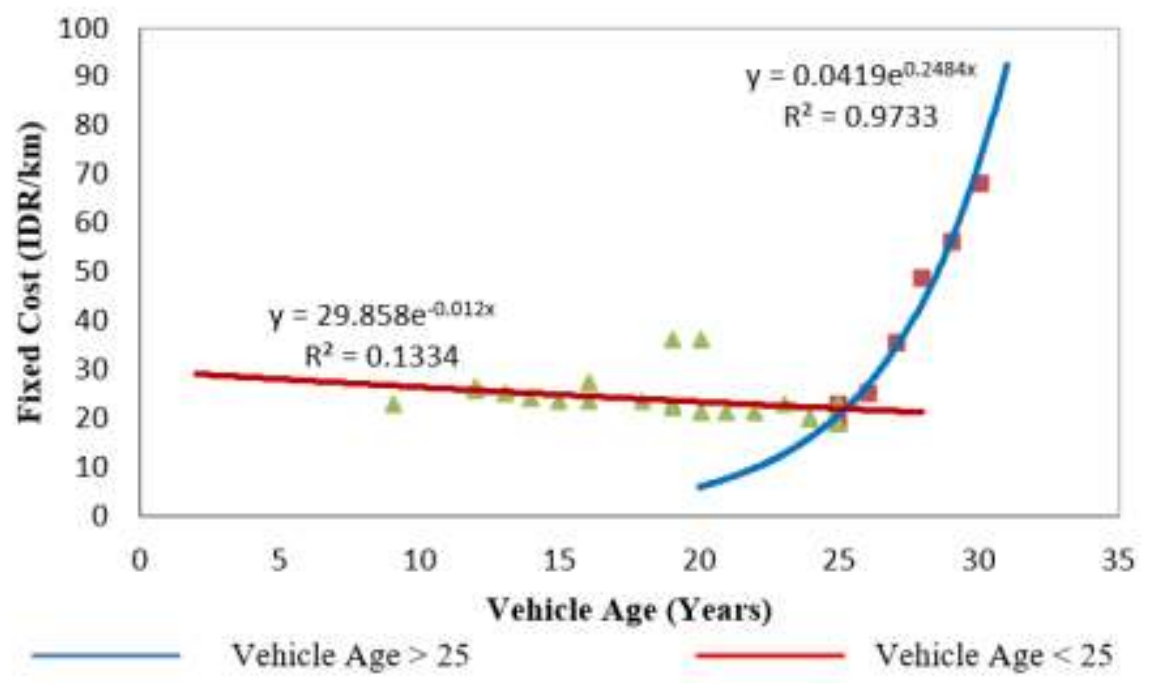

Figure2. Effect of Vehicle Life Age on the Fixed Cost Variable

\subsection{Effect of Vehicle Life Age on the Depreciation Cost Variable}

Variable depreciation costs are expenses that must be provided by the vehicle owner so that at the end of the economic life span, the vehicle owner can change his or her vehicle into a new vehicle. Figure 3 shows the correlation between depreciation costs and vehicle life age, which is at the age 0 to 25 years. The influence of vehicle life age on depreciation costs has a strong correlation, which is indicated by the value of $\mathrm{R}^{2}=0.6472$ or $\mathrm{r}=0.804$ and the percentage increase in the average cost is by $5.4 \%$ per year. In vehicles over the age of 25 years, there is a very strong correlation between depreciation costs and the vehicle life age, which is indicated by the value of $R^{2}=0.9825$ or $r=0.991$ and the percentage increase in the average cost is by $30.4 \%$ per year.

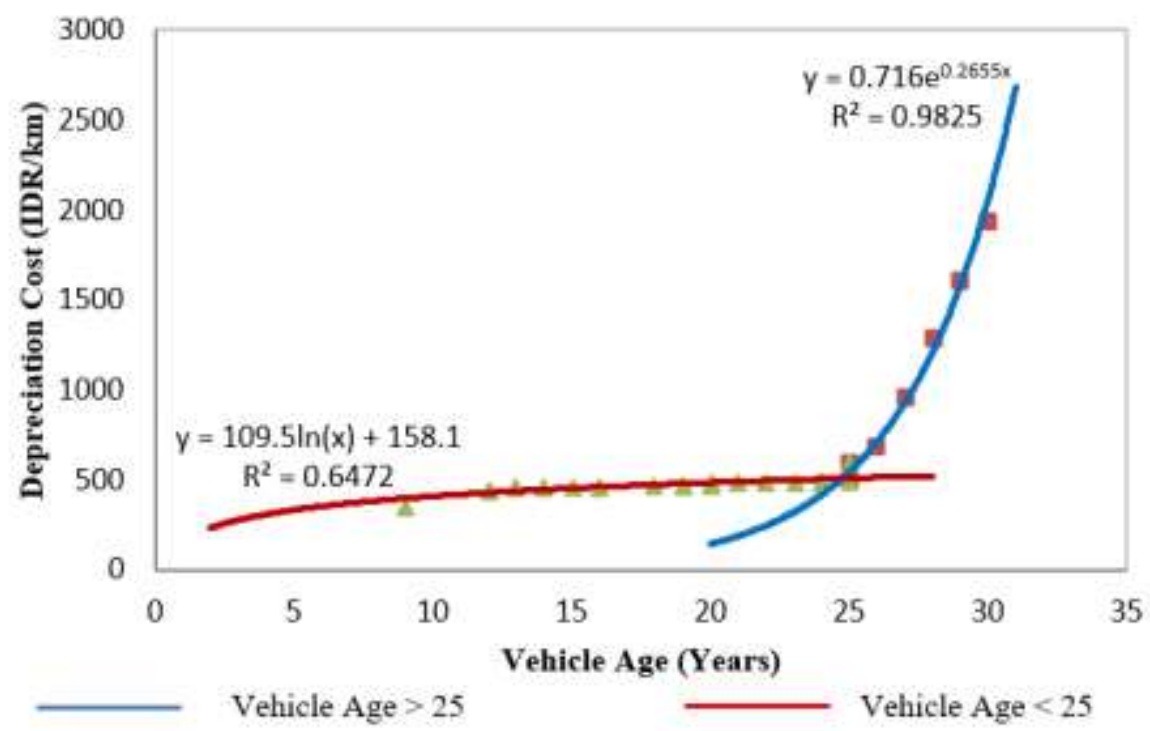

Figure3. Effect of Vehicle Life Age on the Depreciation Cost Variable

\subsection{Effect of Vehicle Life Age on the Maintenance Cost Variable}

The maintenance cost variable here is in the form of service and spare part costs. The variables included in the regression analysis are the cost of replacing parts such as tires, engine oil, axle oil, versatile oil, brake oil, platinum, condensers, spark plugs, 
oil filters, brake canvas, clutch plates, batteries, front and rear wheel bearings, car wash costs, engine service costs, body service costs.

Figure 4 shows the correlation between maintenance costs and vehicle, which is at the age more than 25 years old. There is a strong correlation between the vehicle life age and maintenance costs, which is indicated by the value of $R^{2}=0.7068$ or $r=$ 0.8407 and the percentage increase in maintenance costs is by $4.9 \%$ per year. In vehicles over the age of 25 , there is a very strong correlation between the age of the vehicle and maintenance costs, which is indicated by the value of $R^{2}=0.9114$ or $r=0.955$ and the percentage increase in maintenance costs is by $22.3 \%$ per year.

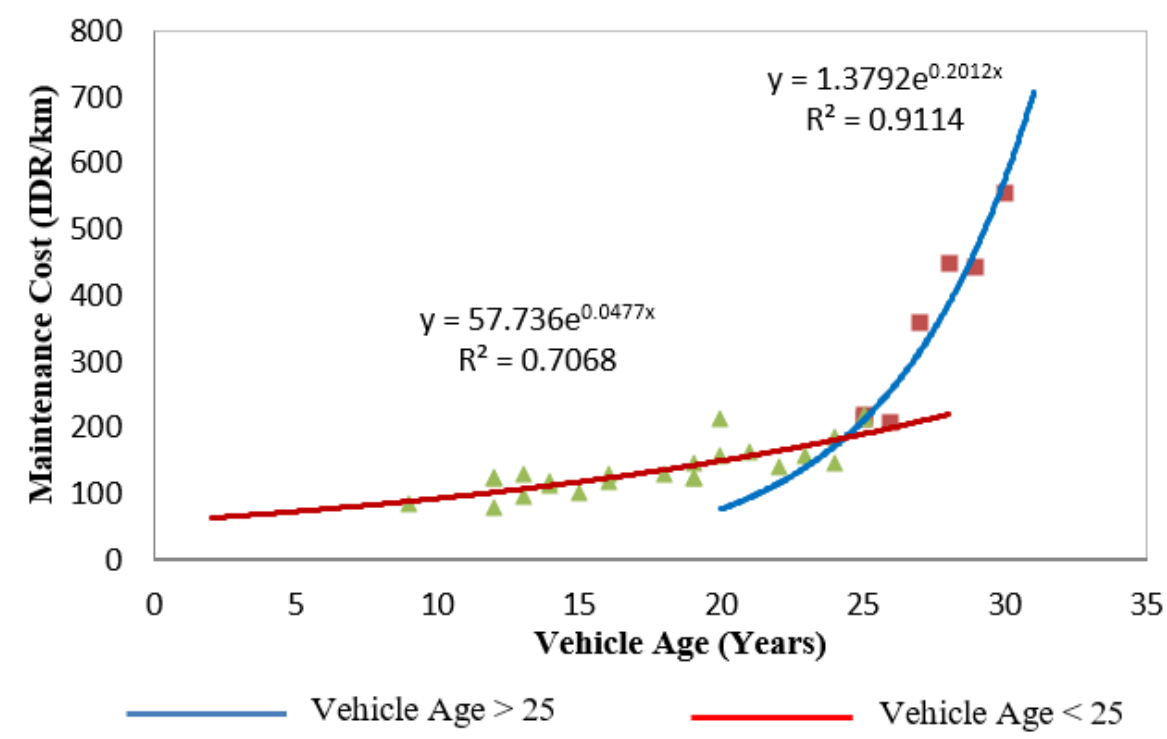

Figure4. Effect of Vehicle Life Age on the Maintenance Cost Variable

\subsection{Effect of Vehicle Life Age on Tire Cost Variables}

Tire cost variable is the price of the costs incurred for tires, both inner and outer tires. Figure 5 shows the correlation between the vehicle life age and the tire cost. The result is a strong correlation between the age of the vehicle and tire costs. It can be seen from the value of $\mathrm{R} 2=0.4942$ or $\mathrm{r}=0.703$ and the percentage increase in tire costs is by $9.7 \%$ per year.

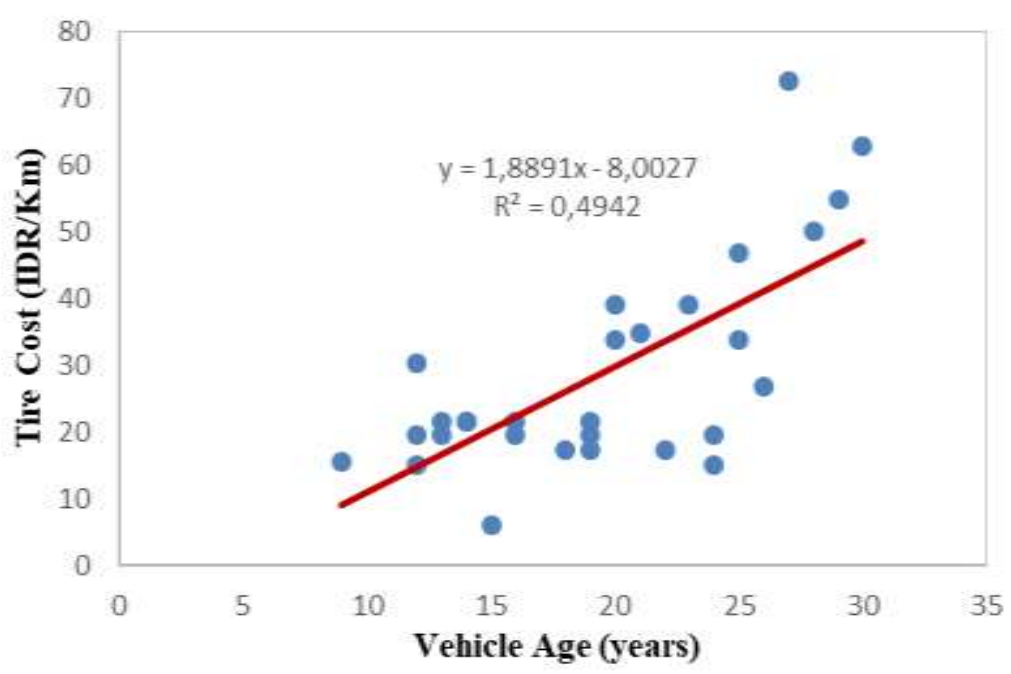

Figure5. Effect of Vehicle Life Age on Tire Cost Variables

\subsection{Effect of Vehicle Life Age on Fuel Cost Variables}

Figure 6 shows the strong correlation between fuel costs and vehicle life age, which can be seen from the value of $R^{2}=$ 0.5226 or $r=0.723$ and the percentage increase in fuel costs by an average is by $1.2 \%$ per year. 


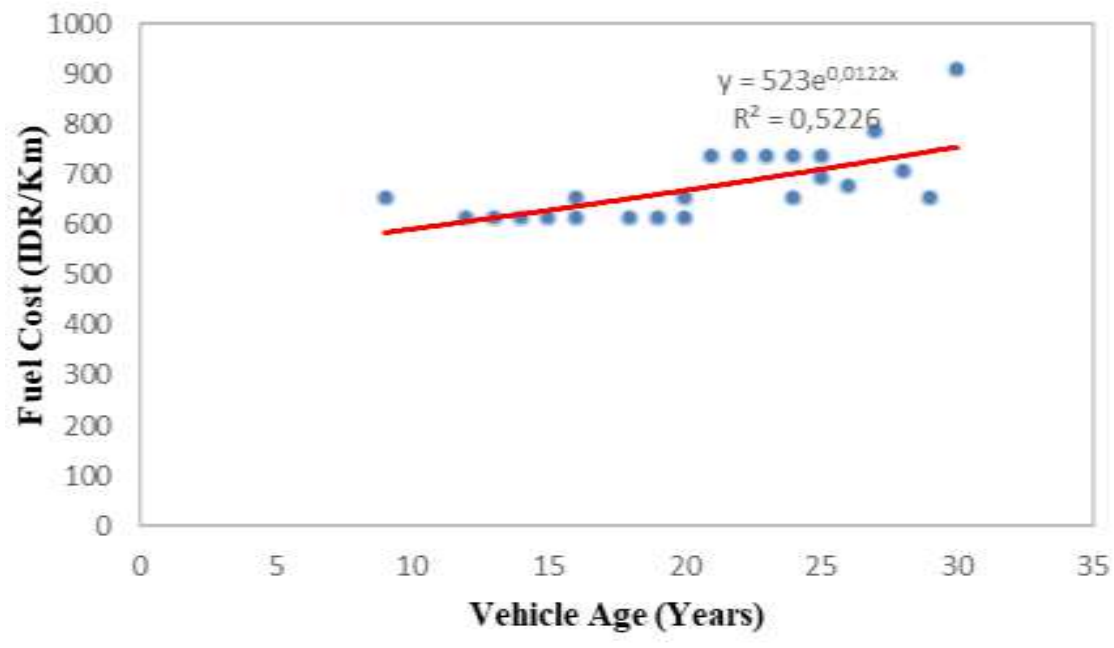

Figure6. Effect of Vehicle Life Age on Fuel Cost Variables

\subsection{Effect of Vehicle Life Age on Oil Cost Variable}

Oil cost variable is the cost incurred for oil needs, namely engine oil, axle oil, gear oil and brake oil. Figure 7 shows the correlation between Vehicle life age and Oil Cost, that is, for vehicles that are up to 25 years old, there is a moderate correlation that can be seen from $\mathrm{R}^{2}=0.211$ or $\mathrm{r}=0.458$ with a percentage increase in average costs of $2.6 \%$ per year. For vehicles over the age of 25 , there is a very strong correlation between the vehicle life age and the oil cost, which can be seen from the value of $R^{2}=$ 0.9328 or $\mathrm{r}=0.966$ and the percentage increase in oil costs on average is by $22.9 \%$ per year.

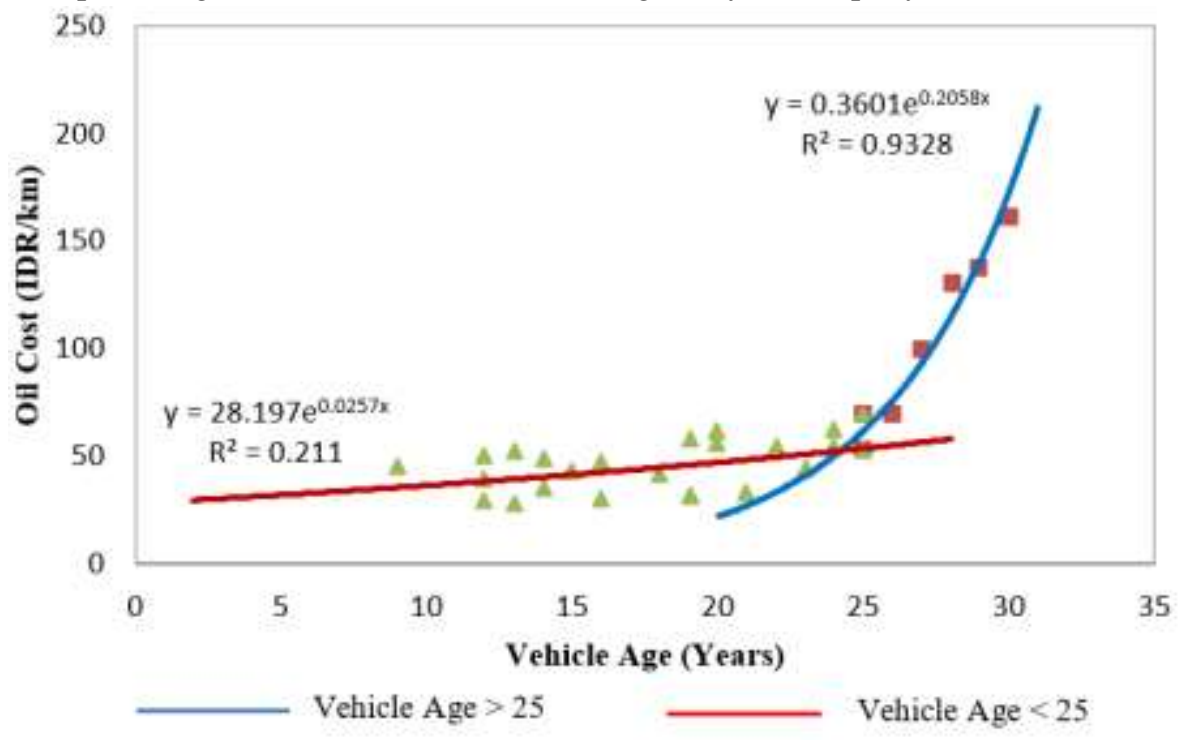

Figure7. Effect of Vehicle Life Age on Oil Cost Variable

\subsection{Average Production Distance}

The average production distance is the distance traveled through by public transportation in one year in $\mathrm{km}$ unit. Figure 8 shows the correlation between the vehicle life age and the average distance of production. The result is that the average distance of production of public transportation will decrease along with the increasing age of vehicles. Until the age of 25 years, the average distance of production of public transportation decreases by $0.6 \%$ per year, but when it is more than 25 years, there is a tendency to decrease the average production distance of public transportation by $21.8 \%$ per year. 
International Journal of Advances in Scientific Research and Engineering (ijasre), Vol 5 (9), September-2019

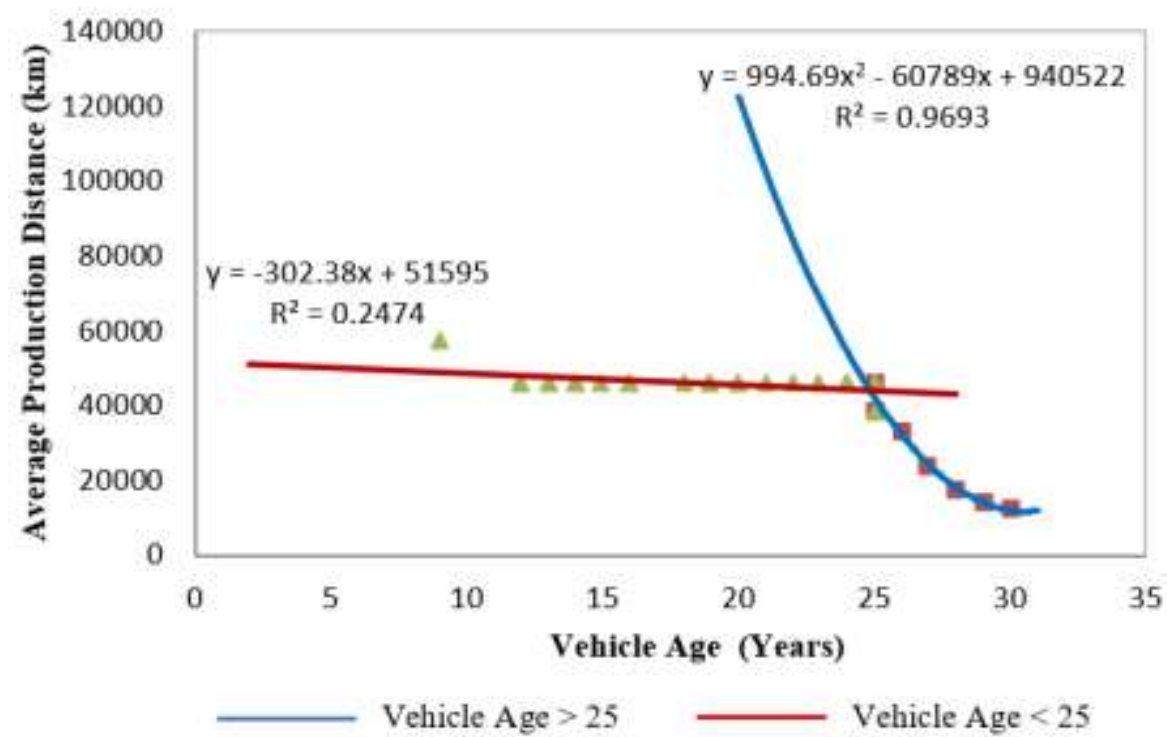

Figure8. Effect of Vehicle Life Age on Average Production Distance

\section{DISCUSSION OF RESULT}

Table3. Recapitulation of Correlation between Vehicle Life Age and VOC

\begin{tabular}{|c|c|c|c|c|c|c|}
\hline No. & Variable & Model Equation & $\mathrm{R}^{2}$ & $\mathrm{r}$ & interpretation & $\begin{array}{l}\text { Sensitivity } \\
\text { per year }\end{array}$ \\
\hline \multirow[t]{3}{*}{1.} & & OC Total & & & & \\
\hline & Age $\leq 25$ & $y=1255,7 e^{0,0127 x}$ & 0,8273 & 0,901 & Very High & $1,27 \%$ \\
\hline & Age $>25$ & $y=12,82 e^{0,1964 x}$ & 0,9896 & 0,995 & Very High & $21,7 \%$ \\
\hline \multirow[t]{3}{*}{2.} & & verage Production Distance & & & & \\
\hline & Age $\leq 25$ & $y=-302,38 x+51595$ & 0,2474 & 0,497 & Moderate & (-) $0,60 \%$ \\
\hline & Age $>25$ & $y=994,69 x^{2}-60789 x+940522$ & 0,9693 & 0,985 & Very High & (-) $21,8 \%$ \\
\hline \multirow[t]{3}{*}{3.} & & ixed Cost & & & & \\
\hline & Age $\leq 25$ & $\mathrm{y}=29,858 \mathrm{e}^{-0,012}$ & 0,1334 & 0,365 & Low & $1,2 \%$ \\
\hline & Age $>25$ & $y=0,04196 e^{0,2484 x}$ & 0,9733 & 0,987 & Very High & $28,2 \%$ \\
\hline \multirow[t]{3}{*}{4.} & & epreciation Cost & & & & \\
\hline & Age $\leq 25$ & $y=109,5 \ln (x)+158,1$ & 0,6472 & 0,804 & High & $5,4 \%$ \\
\hline & Age $>25$ & $\mathrm{y}=0,716 \mathrm{e}^{0,2655 \mathrm{x}}$ & 0,9825 & 0,991 & Very High & $30,4 \%$ \\
\hline \multirow[t]{3}{*}{5.} & & Iaintenance Cost & & & & \\
\hline & Age $\leq 25$ & $y=57,736 e^{0,0477 x}$ & 0,7068 & 0,840 & High & $4,9 \%$ \\
\hline & Age $>25$ & $\mathrm{y}=1,3792 \mathrm{e}^{0,2012 \mathrm{x}}$ & 0,9114 & 0,955 & Very High & $22,3 \%$ \\
\hline \multirow[t]{2}{*}{6.} & & ire Cost & & & & \\
\hline & Age $0-35$ & $y=1,8891 x+8,0027$ & 0,4942 & 0,703 & High & $9,7 \%$ \\
\hline \multirow[t]{2}{*}{7.} & & uel Cost & & & & \\
\hline & Age $0-35$ & $\mathrm{y}=523 \mathrm{e}^{0,0122 \mathrm{x}}$ & 0,5226 & 0,723 & High & $1,2 \%$ \\
\hline \multirow[t]{3}{*}{8.} & & il Cost & & & & \\
\hline & Age $\leq 25$ & $\mathrm{y}=28,197 \mathrm{e}^{0,0257 \mathrm{x}}$ & 0,211 & 0,458 & Moderate & $2,6 \%$ \\
\hline & Age $>25$ & $\mathrm{y}=0,3601 \mathrm{e}^{0,2058 \mathrm{x}}$ & 0,9328 & 0,966 & Very High & $22,9 \%$ \\
\hline
\end{tabular}

To observe the factors that influence the increase in VOC when the age increases, it is necessary to review the VOC determinant variables themselves, including:

1) Depreciation costs in this study are increasing along with increasing age. This is commensurate with the opinion of Oglesby [11] and Jinca [12] stating that the vehicle life age also affects the value of depreciation. The longer the age of the vehicle means the greater the level of shrinkage. 
2) The maintenance costs in this study are increasing along with increasing age. This is commensurate with the research conducted by Handayani [3] in Surakarta stating that the increasing age of the vehicle means the more costs incurred for maintenance/replacement of parts. This is due to the increasing age of the vehicle, engine wear occurs so that to be able to work, it requires repairs by replacing damaged vehicle parts.

3) The tire cost in this research is increasing along with the age increase which is inversely proportional to the research conducted by Handayani [3] in which the increasing vehicle life age means the need for tires decreases because the vehicle is less frequently operated due to maintenance. In this research, there may be other factors that influence tire usage. Because according to Morlok [13], tire usage is influenced by vehicle speed, road slope, type of vehicle, type of road and road alignment.

4) The use of fuel will increase along with age, in this research, fuel consumption increases slowly and has a strong correlation. This is in line with the opinion of Oglesby [11] stating that vehicle life age is also a factor that affects vehicle fuel consumption. The increase in fuel use is not too significant, because maintenance or modification of the engine has been made so that the use of fuel in terms of the trend is not significant.

5) Oil/lubricant costs in this research are increasing along with increasing age, especially after age above 25 years, this is commensurate with the research conducted by Handayani [3] in Surakarta stating that the more vehicles age means the greater consumption of lubricants. This is due to the increasing age of the vehicle, engine wear occurs so that to be able to work, it requires repairs by replacing damaged vehicle parts.

6) Judging from the production distance at the age under 25 years, the production distance is almost the same except after at the age above 25 years, there is a very extreme decline. This is because at an old age, it takes time for repairs and maintenance, and the operators see the number of passenger requests and if the number of passengers is inadequate, the transportation is usually not operating.

Judging from the interpretation of the correlation between the vehicle life ages, it is found that the older the vehicle life age means that the overall VOC will be even greater. This is because the value of the dominant variable affecting the value of the VOC is also getting bigger or rising up. By observing the correlation between the vehicle life age and operating costs, it can be seen that the age of public transportation is efficiently operating in terms of vehicle operating costs.

\section{CONCLUSION}

From the results of calculations and analysis of survey data, it can be concluded that the correlation between the vehicle life age and the VOC of public transportation in Banjar regency has a very strong correlation at the age of $\leq 25$ years with the value of $r=0.901$ and the equation $y=1255.7 \mathrm{e}^{0,0127 \mathrm{x}}$ and at the age of more than 25 years with the value of $\mathrm{r}=0.995$ and the regression equation $\mathrm{y}=12.82 \mathrm{e}^{0,1964 \mathrm{x}}$, where $\mathrm{y}$ is VOC and $\mathrm{x}$ is the vehicle life age. The value of VOC due to the increase in age of the vehicle is that at the age of $\leq 25$ years, the VOC rises slowly in each age increase with an average percentage increase of $1.7 \%$ per year whereas at the age of 25 years. The value of VOC rises drastically with an average percentage increase of $14.5 \%$ per year for each age of motorized vehicles. VOC variable due to increasing age of the vehicle will be a very dominant influence on VOC when the vehicle is > 25 years old, namely variables of fixed cost (licensing), depreciation cost, maintenance cost (service and spare parts), and oil cost.

\section{REFERENCES}

1. Nasution. 2008. Management and Transportation (Manajemen dan Transportasi), Bogor, Ghalia, Indonesia.

2. Ministry of Transportation. 2002. Minister of Transportation Regulation Num. 98 of 2013, concerning Minimum Service Standards for Transporting People with Public Motor Vehicles in Route (Peraturan Menteri Perhubungan No. 98 Tahun 2013, tentang Standar Pelayanan Minimal Angkutan Orang dengan Kendaraan Bermotor Umum dalam Trayek), Ministry of Transportation, Jakarta.

3. Handayani, Dewi. 20003. The Influence of Vehicle Life Age on the Feasibility of Operating a City Bus Public Transport Vehicle in the City of Surakarta (Pengaruh Umur Kendaraan Terhadap Kelayakan Pengoperasian Kendaraan Angkutan Umum Bis Kota di Kota Surakarta), Thesis Program Pasca Sarjana Universitas Diponegoro Semarang.

4. Ministry of Transportation, 2002. Decree of the Minister of Transportation Num. KM. 89 Of 2002, concerning the Mechanism for Determining Tariffs and Formulas for Calculating the Basic Cost of Passenger transportation by public bus, the Ministry of Transportation (Surat Keputusan Menteri Perhubungan No. KM. 89 Tahun 2002, tentang mekanisme penetapan tarif dan formula perhitungan biaya pokok angkutan penumpang dengan mobil bus umum), Ministry of Transportation, Jakarta.

5. Tjokroadiredjo, R.E., 1990. Transportation Engineering Economics (Ekonomi Rekayasa Transportasi), ITB, Bandung.

6. Sehgal, S.B. \& Bhannot, K.L., 1978. A Text Book On Highway Engineering and Airports, S. Chand \& Company LTD, ram Nagar, New Delhi. 
7. Sudjana, 1988. Statistical Methode (Metode Statistik), Bandung: Tarsito.

8. Akbar, Usman, 2006. Social Research Methodology (Metodologi Penelitian Sosial), Jakarta: Bumi Aksara.

9. Siregar, S. 2013. Quantitave Research Methodes (Metode Penelitian Kuantitatif). Cetakan kedua, Kencana, Jakarta.

10. Radam, Iphan F., Setiadji, Bagus H., \& Mulyono, Agus T., 2015. Influence of Service Factors in the Model of Public Transport Mode: a Banjarmasin-Banjarbaru Route Case Study, International Journal For Traffic and Transport Engineering, 5(2), 108-119.

11. Oglesby, Clarkson H. \& Hicks, R. Gary. 1993. Highway Engineering (Teknik Jalan Raya). Jakarta: Erlangga.

12. Jinca, M. Y. 2001, Collection of Lecture Materials (Kumpulan Bahan Kuliah), Program Studi Teknik Transportasi, Universitas Hasanuddin, Makassar.

13. Morlok, E. K. 1985, Introduction to Transportation Engineering and Planning (Pengantar Teknik dan Perencanaan Transportasi). Jakarta: Erlangga. 